\title{
RGS1 Gene
}

National Cancer Institute

\section{Source}

National Cancer Institute. RGS1 Gene. NCI Thesaurus. Code C24735.

This gene plays a role in signal transduction, protein binding and B-cell activation. 